\title{
PRACTICE
}

\section{Teaching Research Skills to Vocational Learners: Teaching Chefs to Research}

Willa Zhen, Culinary Institute of America

\begin{abstract}
This article focuses on teaching and mentoring coursebased undergraduate research in a vocationally focused higher education setting. At the Culinary Institute of America (CIA), students are immersed in hands-on experiential classes. Their education begins with basic culinary techniques, and they gradually progress toward more specialized cooking skills such as the techniques of specific world regions or the production of specialty products such as chocolates and wedding cakes. The author discusses pedagogical techniques used to teach these learners, who are not the usual participants in independent research projects during a senior capstone. This article examines how to blend and utilize hands-on, experiential activities as part of teaching data gathering and the research process.
\end{abstract}

Keywords: capstone experiences, culinary education, experiential research, Japanese cuisine, undergraduate research, vocational education

doi: $10.18833 /$ spur/4/2/6

Many years ago, a conversation with a colleague was instructive. The colleague - an older, take-no-prisoners former Marine-first worked as a "kitchen boy" (his term) in a restaurant when he was a teenager. Upcoming curriculum changes at the Culinary Institute of America (CIA) was the topic of the conversation. The article author planned to add research components to her courses in the school's liberal arts department. The colleague claimed not to understand some of these pedagogical ideas and responded, "I'm a cook. What I do is cook." He presented a façade of incomprehension of the world of research and academia, yet he actually was well versed in many things and was hardly just a cook.

This conversation has lingered in memory because students have made similar comments over the years in response to questions about research. When they have encountered difficulties in writing an essay or completing a research assignment, they have sometimes relied on the same crutch of the older colleague: they are just cooks. Of course, this is far from accurate. These students, just like the colleague, are far more than cooks. They are college students whose fields of study happen to focus on food. Because they are college students, they are expected to engage with higher order thinking skills like their peers at other institutions.

This article discusses the approaches used in teaching culinary students how to research. First, an overview of culinary education is provided that includes its evolution from a traditional focus on skills-based, repetitive learning. Next, learning focused on the students' interests and agency is analyzed in relation to the previous pedagogical experiences of the students. Outlined are the difficulties and successes in breaking down the barriers of research to students. This is often the most difficult task, as many CIA students do not see themselves as researchers and do not view themselves as capable of completing such projects. Much initial work involves dispelling the myth that, because they are hands-on learners and cooks, they are less capable of "book-learning" or advanced research. Third, ways to make the research process approachable to novice researchers are discussed. Much work involves teaching students to think creatively about data and sources. The research process is taught by pairing an 
experiential activity with academic readings. Many learners have been taught to think that sources mean written texts. In the capstone experience described here, sources are emphasized as multisensory and capable of incorporating anything that can be touched, smelled, examined, listened to, watched, or even tasted. The article concludes by pointing out that teaching and mentoring course-based undergraduate research projects are important to the college experience. This experience is especially crucial for students in vocationally based programs who had not previously considered themselves to be capable of research or to learn the skills of research: critical thinking, analysis, and independent inquiry.

\section{An Overview of Culinary Education}

There are hundreds of higher educational institutions with culinary arts majors (American Culinary Federation n.d.). The CIA was one of the first institutions to focus on professional culinary training in the United States. Founded in 1946 as the New Haven Restaurant Institute in downtown New Haven, CT, its original purpose was to train World War II veterans in a trade. In the intervening years, the school changed its name and location, settling on the Culinary Institute of America at its present-day site in Hyde Park, NY. Over the years, the institution has gained a reputation as one of the preeminent institutions for culinary training. This reputation started in the 1970s not long after the school moved to Hyde Park and the onset of a gourmet culture in the United States (see Kamp 2006). Life Magazine touted it as "The Harvard of Haute Cuisine" (1979). Today, graduates of the CIA top the best-of lists in restaurants and the hospitality industry and include food celebrities.

Historically speaking, culinary education has more closely aligned with trade or craft training rather than university studies (Ferguson 2004, 131-148; Fine 1996; Ray 2016, 111-154; Symons 2004, ix; Trubek 2000, xi). Like craft and trade training, culinary education has for a long time emphasized the replication of skills. Novice cooks start by mimicking the actions taught to them by instructors and mentors. It is only after mastery of the foundational skills that cooks are then encouraged to develop their style or flair: to "improvise" (Deutsch 2018). However, in the wake of World War II, occupations and trades became increasingly professionalized (Wilensky 1964), the processes by which members attempt to transform their occupation into a profession. The process of professionalization is, in part, a response to changing socioeconomic conditions and new regimes of value in labor that privileges professionalized work over manual labor. In the post-World War II period, the process of professionalization occurred in many industries.

Cooking, too, has become increasingly professionalized in different parts of the world since the post-World War II period (see Mack 2012). The CIA was among the first culinary training institutions established in the United States. Its founding mission was to professionalize culinary training by offering a standardized curriculum, setting instructional materials, conducting experiential training in kitchen-laboratories, and providing theoretical training in classrooms. This vision of professional culinary education conflicted with the long-established models of training via apprenticeship (formal or informal) and on-the-job training in kitchens.

Historically, the CIA focused on a two-year vocational curriculum. As the reputation of the institute grew, programs have been added, branch campuses opened, and the depth and breadth of training increased. Over the last 20 years, the CIA has transitioned to an undergraduate degree model with majors in applied food studies, culinary science, food business management, and hospitality management. Although many students still choose to take an associate's degree in either culinary arts or baking and pastry arts, students are increasingly opting to continue their education beyond this level.

It could be argued that these changes indicate the "professionalization" of cooking, particularly through formal instruction via cooking schools. This has occurred as a response to broader socioeconomic changes: culinary students need academic skills and academic degrees in today's economy. Culinary programs have attempted to mediate these issues by transitioning toward more academically focused programs in addition to skills training. To illustrate, the Culinary Institute of America and Johnson \& Wales University, the two largest postsecondary culinary institutions, provide bachelor's degrees. It is worth pointing out that Johnson \& Wales changed its name to Johnson \& Wales University in 1988-a meaningful step reinforcing the shift to academic credentialing. At CIA, this shift to a more academically focused model has meant the creation of new majors, specializations, and programs. Several of these programs require a senior capstone as part of graduation requirements.

This article focuses on a capstone course in the Japanese Cuisine Concentration. The one-semester Japanese Cuisine Concentration takes place on the CIA's main campus in New York, as well as in Japan. For this concentration, students undertake a two-week intensive study trip to Japan, attend specialized culinary courses on Japanese food co-taught by a CIA chef-instructor and an instructor from Tsuji Culinary Institute in Japan, pursue an intensive sake certification, take an academic course on Japanese food and history, and complete a research capstone project. At the end of the concentration, the students demonstrate their expertise by serving a multi-course kaiseki meal, a traditional multicourse dinner that is often considered the epitome of Japanese fine dining, as well as present a research poster to the public. 


\section{Teaching Students to See Themselves as Researchers}

As part of the Japanese Cuisine Concentration, the students complete individual research projects over a semester to develop their critical thinking, creativity, and intellectual independence. The first task - the most daunting one - is empowering the students to conduct research. Many of the capstone students are unfamiliar with, and perhaps even intimidated, by the idea of research. When asked what the term research calls to mind, they picture an all-tooserious academic slaving away in a remote lab trying to find a solution for a grand world problem. On the other extreme, the term research is synonymous with looking up something via Google. They are accustomed to an idea of research as fact-finding: obtaining an answer from Google, Wikipedia, or some other quick Internet source. They had never considered that research means deep thinking and investigation about their ideas and interests.

The approach to mentoring undergraduate research discussed here is a social research approach, drawing from the instructor's training as an anthropologist and food studies scholar. This approach is emphasized because it takes into account multiple types of knowledge and different ways of seeing the world. Social research "produces knowledge and helps us come to understand the social world and our place in it" (Leavy 2017, 5). Social research emphasizes exploration, description, explanation, community change or action, evaluation, and to evoke, provoke, or unsettle people's perceptions (Leavy 2017, 5-7). This course prioritized exploration, description, explanation, and evaluation as the major skills in undergraduate research.

Social research incorporates the idea that humans are researchers by nature-in other words, they are curious about the world around them and want to understand it. This certainly describes the students who enter the Japanese Cuisine Capstone incredibly curious and eager to learn about Japanese food and foodways. Prior to the course, much of their intellectual probing has taken a culinary focus. They have learned to test recipes, try out concepts, and see if different flavors and textures can work well together. Translating this spirit of inquiry and intellectual curiosity from the kitchen to the classroom is often the most difficult part, because the students do not see themselves as capable academic researchers. In the course, the goal is to empower students to see that research can be an enjoyable activity and to empower them to see themselves as researchers. By recognizing and encouraging students to start with what they know, this approach acknowledges that every student has agency and importance as a researcher.

An approach of many social researchers is to start with what people already know how to do: explore, describe, and explain. At the start of the semester, the students and instructor take a two-week study tour to Japan, visiting food producers, farms, wholesale markets (including Toyosu Fish Market, the successor to the renowned Tsukiji Fish Market), restaurants, chefs, and cooking schools to learn about Japanese food culture and its food system. During this trip, each student documents their experiences in a field journal. Factual data is recorded (e.g., places visited, people met), but the majority of the journal prompts and data is focused on the sensorial. Students are given a reading on doing ethnography and writing field notes before departure. They are expected to record the following in their journals:

- What did you see/touch/smell/hear/taste?

- What did you feel?

After the completion of the trip, students reflect upon and evaluate their experiences through the following prompts:

- What impressed you about Japan?

- What was challenging or disappointing about Japan?

- What do you still have questions about? What don't you understand?

- What would you like to learn more about that might serve as a potential research topic?

After the trip, students are asked to reflect on their journals. On what did they focus their attention? What surprised them? What caught their eye? Discussing their personal experiences in a group setting becomes the first step in brainstorming project topics. Many of the students thought about their best food experience and used that as their initial research topic.

The students then meet with research librarian Raven Fonfa to discuss library resources and to further refine their research topics, seeking to ascertain if their topic is researchable and has sufficient sources. They also work on compiling an annotated bibliography that accounts for existing research on their topic. Their goal is to produce a research paper that incorporates primary source data along with secondary sources, as well as to create a public poster presentation at the end of the semester for the campus community.

\section{Identifying Sources}

One struggle experienced by students was identifying appropriate sources. They may think that sources mean only academic sources - scholarly volumes or academic journals. They have not considered material objects, graphic novels and comics, recipes, menus, or art as valid sources and data. Most of the course is spent thinking through sources and the role of non-academic sources in providing information and data.

After the study trip to Japan, a class discussion is held about Japanese food. On a whiteboard, three categories are outlined: what students knew about Japanese food before 
visiting Japan, what they learned about Japanese food during the study trip, and what they learned about Japanese food from the introductory survey readings assigned. Through this conversation, students begin to see how their knowledge changes from the very personal to knowledge informed by historical, cultural, and social contexts through academic sources. As the course progresses, students are encouraged to start with familiar sources and to explore those that extend beyond immediate knowledge.

Community resources become important in shifting student understandings of a topic. With the support of the CIA's Archives and Special Collections, students are exposed to Japanese menus in the United States and Japan. A class session is devoted to a meeting with archivist Nicole Semenchuk, who provides Japanese and Japaneseinspired menus from the more than 40,000 menus in the collection. Students are encouraged to touch, smell, examine-everything but lick! - the menus. Students participate in a conversation about what draws their eye and ponder the following questions:

- What do you notice about the menus? What are your first impressions?

- What items are being served?

- How is Japanese food represented?

- Who is representing Japanese food over different generations?

- Who is this food for? Japanese or non-Japanese diners?

Afterward, the discussion centers on how menus (as well as cookbooks, recipes, and other written culinary sources) can be used as data in research.

The CIA's proximity to Vassar College's Frances Lehman Loeb Art Center, which holds a collection of Asian artifacts, also is a bonus. In past visits, Margaret Vetare, curator of public education, has brought out items from the archives, including several ukiyo-e prints from the lateseventeenth to nineteenth centuries. Most of the students had never seen ukiyo-e prints up close. Some of these prints incorporate themes and trends used in Japanese food such as folklore, seasonality, and natural landscapes. The center's small collection of material objects, chiefly a calligraphy set and tea ceremony utensils, help students consider how aesthetics translate into Japanese culinary practices and other artistic endeavors.

Japanese pop culture also is brought into the classroom through teaching about manga (graphic novels). Most of the students first learned about Japanese culture through reading manga. To most Americans, graphic novels suggest comic books about action heroes for young readers. In Japan, manga can cover all literary genres written for readers of all ages. There is a specific subgenre known as "cooking manga" or "gourmet manga."
Food is a central part of the plot in cooking graphic novels. Two well-known series, Yakitate!! (Freshly Baked) and Oishinbo (The Gourmet), use food to engage with issues of identity, belonging, taste, and aesthetics. In the course, the students read the opening chapters of Yakitate!!, which feature a young man, Azuma Kazuma, who is trying to make the perfect loaf of bread for the Japanese people (Hashiguchi 2007). He argues that Japan should have a national loaf as is the case with the French, Italians, and other Europeans. The protagonist's grandfather, a rice farmer, scoffs at the notion of bread as a Japanese staple. Yakitate!! is read along with selections from anthropologist Emily Ohnuki-Tierney's Rice as Self: Japanese Identities through Time (1993) to consider the symbolic importance of rice to Japanese national identity.

Oishinbo follows the story of journalists at a Japanese newspaper and their mission of creating the "Ultimate Menu" of Japanese foods and drinks. Throughout the series, they visit food producers, chefs, and gourmets to compile their list. Each chapter focuses on a specific food or beverage or a concept related to gastronomy. The class reads the chapter "The Tea Master and the Strawberry" on Japanese aesthetics and taste in terms of pairing foods with tea (Kariya, Hanasaki, and Han 2009) and watch a video on the tea ceremony. By pairing an experiential activity with academic readings, students are taught how to gather data, build analyses, and tie primary source material to secondary sources.

\section{Pulling It All Together}

After several weeks of focused instruction pairing experiential activities with foundational readings on the research process or Japanese foodways, students use the class time to write and work, consulting with the instructor as needed to brainstorm ideas or seek solutions to problems encountered in the research process. Students focus on the description, explanation, and exploration of their topics. Project subjects have included wagashi (traditional Japanese sweets), katsuobushi (dried, fermented, and molded skipjack tuna), matcha, rice, and manga and food (see Table 1). A course requirement is a 20-page research paper on their topic, in which they present a thesis statement and cite a range of scholarly and primary sources to support their argument.

Another course requirement is a public presentation of the projects. The students create poster boards and display them for a presentation hour at the student commons (see Figure 1). They discuss their research with invited guests (faculty, staff, and other students), as well as others who wish to learn more about their work. This process involves the explanation and evaluation aspects of research, as the students must summarize their work to fit into the space of a poster board. They also develop talking points on the major facts and highlights of their research, and explain their work to others so that it is approachable and intelligible. 


\section{Conclusion}

Culinary students are not the usual audience for collegelevel research courses. Yet they are the types of students who have the most to gain from research experiences, because these compel them to challenge, question, and think in new ways. They may not have an opportunity to do so again in the future. For many of the students discussed here, this was the only research class they attended in their academic career. As one student wrote in an evaluation, "This class was very helpful because it was able to

\section{TABLE 1. Projects from Fall 2019}

\begin{tabular}{|c|c|c|c|}
\hline Research topic & Project description & Sources used & Thesis \\
\hline Wagashi & $\begin{array}{l}\text { Wagashi are traditional Japanese sweets. } \\
\text { Wagashi are usually paired with matcha } \\
\text { (powdered green tea). This project inves- } \\
\text { tigated the interplay between wagashi and } \\
\text { design, detailing how wagashi combines art, } \\
\text { aesthetics, and culture as well as taste. }\end{array}$ & $\begin{array}{l}\text { - Wagashi molds used in making these } \\
\text { - Wagashi cookbooks } \\
\text { - Wagashi design books } \\
\text { - Field notes, photos, and videos from } \\
\text { a wagashi demonstration at Toraya } \\
\text { Confectionary Co. in Kyoto, a confec- } \\
\text { tioner in operation since the sixteenth } \\
\text { century that provides sweets to the } \\
\text { Japanese imperial family } \\
\text { - Email interviews with Japanese chefs } \\
\text { and wagashi confectioners } \\
\text { - Scholarly secondary sources }\end{array}$ & $\begin{array}{l}\text { - Wagashi design reflects } \\
\text { Japanese ideals of craft, } \\
\text { skill, art, and taste. } \\
\text { - Although wagashi designs } \\
\text { have been updated over } \\
\text { time, the core principles of } \\
\text { how these sweets can be } \\
\text { produced and decorated } \\
\text { follow strict guidelines. } \\
\text { They suggest an unwavering } \\
\text { sense of core identity. }\end{array}$ \\
\hline Katsuobushi & $\begin{array}{l}\text { Katsuobushi is a type of dried, fermented, } \\
\text { and smoked skipjack tuna. It is an essen- } \\
\text { tial ingredient in Japanese cooking, and its } \\
\text { traditional production methods are slowly } \\
\text { disappearing as Japanese cooks shift to using } \\
\text { instant products that mimic the taste at a } \\
\text { fraction of the cost. Traditional katsuobushi } \\
\text { producers are also aging and dying with no } \\
\text { younger producers to learn the craft. This } \\
\text { project focused on katsuobushi production, } \\
\text { explaining that its traditional production } \\
\text { methods, lack of a new generation of produc- } \\
\text { ers, change in home cooking practices, and } \\
\text { climate change impacts on fish stocks are } \\
\text { endangering this food product. }\end{array}$ & $\begin{array}{l}\text { - Field notes, photos, and videos from a } \\
\text { katsuobushi cooking demonstration in } \\
\text { Japan } \\
\text { - Field notes, photos, and videos from } \\
\text { a visit to Toyosu Fish Market, a large } \\
\text { wholesale market in Tokyo } \\
\text { - Cookbooks } \\
\text { - Recipe testing and tasting different } \\
\text { grades of katsuobushi } \\
\text { - Scholarly secondary sources }\end{array}$ & $\begin{array}{l}\text { - Katsuobushi is an endan- } \\
\text { gered traditional food. } \\
\text { Despite the fact that } \\
\text { Japanese cooks consider it } \\
\text { the "soul" of Japanese cui- } \\
\text { sine, modern cooks are not } \\
\text { interested in cooking with } \\
\text { it or learning how to pro- } \\
\text { duce it. }\end{array}$ \\
\hline Matcha & $\begin{array}{l}\text { Matcha is a type of finely ground green tea } \\
\text { powder used in the traditional Japanese tea } \\
\text { ceremony. This project focused on the culture } \\
\text { of the Japanese tea ceremony and the ways } \\
\text { that matcha connects to Japanese aesthetics, } \\
\text { philosophy, and spirituality. }\end{array}$ & $\begin{array}{l}\text { - Field notes, photos, and videos from } \\
\text { two matcha demonstrations in Japan } \\
\text { - Cookbooks } \\
\text { - Matcha instruction manuals } \\
\text { - Matcha bowls and tools } \\
\text { - Practicing matcha preparation } \\
\text { - Scholarly secondary sources }\end{array}$ & $\begin{array}{l}\text { - Matcha represents Japanese } \\
\text { identity. Matcha is not just } \\
\text { a cup of tea; it is symbolic } \\
\text { of Japanese ideals regarding } \\
\text { behavior and taste. }\end{array}$ \\
\hline $\begin{array}{l}\text { Rice and } \\
\text { Japanese identity }\end{array}$ & $\begin{array}{l}\text { This project focused on the ritual of rice } \\
\text { production from the paddy to the rice bowl, } \\
\text { focusing on how the process of rice con- } \\
\text { sumption is a ritual for Japanese people: from } \\
\text { the selection of rice varietals and age of the } \\
\text { rice to the cooking methods used and the } \\
\text { serving and eating of rice in specific contexts } \\
\text { such as celebrations of the new rice harvest. }\end{array}$ & $\begin{array}{l}\text { - Field notes, photos, and videos from } \\
\text { a visit to a rice paddy in the Kansai } \\
\text { region of Japan } \\
\text { - Tasting notes of new-harvest Japanese } \\
\text { rice } \\
\text { - Eighteenth- and nineteenth-century } \\
\text { Japanese woodblock prints featuring } \\
\text { rice harvests } \\
\text { - Cookbooks } \\
\text { - Menus } \\
\text { - Scholarly secondary sources }\end{array}$ & $\begin{array}{l}\text { - Japanese- produced rice } \\
\text { is symbolic of Japanese } \\
\text { identity. } \\
\text { - Even as rice consumption } \\
\text { declines, Japanese people } \\
\text { will never give up on using } \\
\text { rice in rituals and ceremo- } \\
\text { nies, as well as celebrating } \\
\text { the importance of the crop } \\
\text { in Japanese foodways. }\end{array}$ \\
\hline Food in manga & $\begin{array}{l}\text { Manga are graphic novels. There are manga } \\
\text { on all topics for all ages. A popular category } \\
\text { of manga is focused on food. This project } \\
\text { explored how food and Japanese identity } \\
\text { intersect in manga. }\end{array}$ & $\begin{array}{l}\text { - Manga as primary sources, focusing } \\
\text { on the series Oishinbo (The Gourmet) } \\
\text { - Scholarly secondary sources }\end{array}$ & $\begin{array}{l}\text { - Manga reveals insights into } \\
\text { Japanese tastes and food } \\
\text { trends. }\end{array}$ \\
\hline
\end{tabular}


FIGURE 1. A Student Project on Rice Featuring Samples of Different Varietals of Rice Used in Japanese Cooking

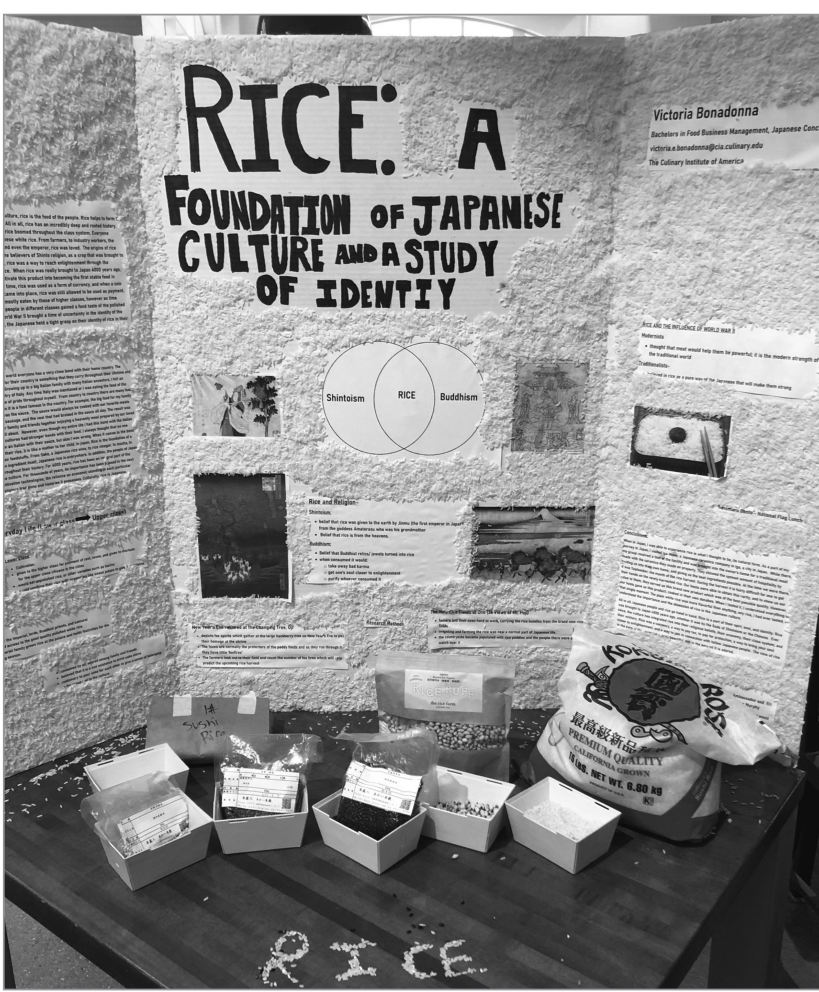

take our knowledge from Japan, our kitchen class, and our history class and bring them all together with the material learned in the capstone class." In an increasingly complicated and interconnected world where misinformation flows quickly and widely, teaching students to engage with information through critical thinking and creativity is vital. As this article has demonstrated, intellectual independence is a life skill that can be developed through academic research projects.

\section{References}

American Culinary Federation. n.d. "Accredited Postsecondary Programs." Accessed 1 May 2020. www.acfchefs.org/ACF/Education/Enrollment/Postsecondary/ACF/Education/Enrollment/ Postsecondary/default .aspx?hkey=5ea29b5a-d0f1-4d8f-bc8dc81ce643c519

Deutsch, Jonathan. 2018. "Can Improvisation Save Culinary Education?" Liminalities 14(1): 169-184.
Ferguson, Priscilla Parkhurst. 2004. Accounting for Taste: The Triumph of French Cuisine. Chicago: University of Chicago Press.

Fine, Gary Alan. 1996. Kitchens: The Culture of Restaurant Work. Berkeley: University of California Press.

"The Harvard of Haute Cuisine: A Rigorous Training Ground for America's Future Chefs." May 1979. Life Magazine, pp. 54-60.

Hashiguchi, Takashi. 2007. Yakitate!! Japan, San Francisco: Viz Media.

Kamp, David. 2006. The United States of Arugula: How We Became a Gourmet Nation. New York: Broadway Books.

Kariya, Tetsu, Akira Hanasaki, and Kelle Han. 2009. Oishinbo, a La Carte. Translated by Tetsuichiro Miyaki. San Francisco: Viz Media.

Leavy, Patricia. 2017. Research Design: Quantitative, Qualitative, Mixed Methods, Arts-Based, and Community-Based Participatory Research Approaches. New York: Guilford Press.

Mack, Glenn R. 2012. "Professionalism in Culinary Arts: Perceptions and Assessments for Training and Curricular Design." PhD Diss., Nova Southeastern University.

Ohnuki-Tierney, Emiko. 1993. Rice as Self: Japanese Identities through Time. Princeton: Princeton University Press.

Ray, Krishnendu. 2016. The Ethnic Restaurateur. London: Bloomsbury Publishing.

Symons, Michael. 2004. A History of Cooks and Cooking. Chicago: University of Illinois Press.

Trubek, Amy. 2000. Haute Cuisine: How the French Invented the Culinary Profession. Philadelphia: University of Pennsylvania Press.

Wilensky, Harold L. 1964. "The Professionalization of Everyone?" American Journal of Sociology 70(2): 137-158. doi: $10.1086 / 223790$

\section{Willa Zhen}

Culinary Institute of America, w_zhen@culinary.edu

Willa Zhen is professor of liberal arts and food studies at the Culinary Institute of America. Trained as a social anthropologist, she earned a PhD from SOAS, the University of London. Her research has focuses on culinary training, skills, and identity among cooks in Guangzhou, China. She is the author of Food Studies: A Hands-on Guide (Bloomsbury, 2019). 